\title{
Skeletal changes produced by cervical and parietal headgears: a cephalometric evaluation
}

\author{
Avaliação cefalométrica das alterações esqueléticas decorrentes do uso do \\ aparelho extrabucal com ancoragens cervical e parietal \\ Anderson Jaña ROSA ${ }^{a *}$ (i), Oswaldo de Vasconcellos VILELLA ${ }^{a}$ (i) \\ a UFF - Universidade Federal Fluminense, Faculdade de Odontologia, Departamento de Ortodontia, Niterói, RJ, Brasil
}

How to cite: Rosa AJ, Vilella OV. Skeletal changes produced by cervical and parietal headgears: a cephalometric evaluation. Rev Odontol UNESP. 2021;50:e20210022. https://doi.org/10.1590/1807-2577.02221

\begin{abstract}
Resumo
Introdução: A força extrabucal é a estratégia mais comum para corrigir a má oclusão de Classe II de Angle, restringindo e redirecionando o crescimento maxilar. Objetivo: Avaliar as alterações esqueléticas decorrentes do uso do aparelho extrabucal, com ancoragens cervical e parietal, associado ao aparelho ortodôntico fixo, em pacientes em crescimento com má oclusão de Classe II (Angle) tratados na clínica de um centro de treinamento ortodôntico. Material e método: As idades ao início e ao término do tratamento, o tipo de ancoragem, e os valores de algumas variáveis cefalométricas foram obtidos dos arquivos clínicos. Após a aplicação dos critérios de inclusão e exclusão, foram selecionados 56 prontuários. Em seguida, a amostra foi dividida em dois grupos, de acordo com a ancoragem: cervical $(n=30)$ e parietal $(n=26)$. As diferenças entre os valores inicial (T1) e final (T2) das variáveis cefalométricas SNA, SNB, ANB, AO-BO, GoGn.SN e AFI (porcentagem da altura facial inferior em relação à altura facial total) foram avaliadas em ambos os grupos. Resultado: Diferenças significativas entre T1 e T2 foram encontradas em relação às variáveis SNB e ANB em ambos os grupos. A variável AO-BO apresentou diferença estatisticamente significante apenas no grupo cervical. As demais variáveis não apresentaram diferenças significantes entre T1 e T2. Conclusão: As alterações esqueléticas decorrentes do uso das ancoragens cervical e parietal foram muito semelhantes. Houve diminuição da discrepância anteroposterior entre a maxila e a mandíbula devido ao deslocamento anterior da mandíbula, sem alterações verticais significativas.
\end{abstract}

Descritores: Aparelhos de tração extrabucal; má oclusão de Angle Classe II; ortodontia.

\begin{abstract}
Introduction: Extraoral strength is the most common strategy to correct Angle Class II malocclusion, restricting and redirecting the maxillary growth. Objective: To evaluate the skeletal changes resulting from the use of headgear, with cervical and parietal anchorages, associated with a full fixed orthodontic appliance, in growing patients with Class II malocclusion (Angle) treated in the clinic of an orthodontic training center. Material and method: The ages at the beginning and end of the treatment, anchorage type, and the values of some cephalometric variables were obtained from the clinical files. After applying the inclusion and exclusion criteria, 56 patient files were selected. Then, the sample was divided into two groups, according to the anchorage type: cervical $(n=30)$ and parietal $(n=26)$. The differences between the initial (T1) and final (T2) values of cephalometric measurements SNA, SNB, ANB, AO-BO, GoGn.SN and LHF (percentage of lower facial height to total facial height) were evaluated in both groups. Result: Significant differences between T1 and T2 were found relative to SNB and ANB variables in both groups. The AO-BO variable presented a statistically significant difference only in the cervical group. The remaining variables did not show significant differences between T1 and T2. Conclusion: The skeletal changes resulting from the use of cervical or parietal anchorage were very similar. There was a decrease in the sagittal discrepancy between the maxillary bones due to forward displacement of the mandible, without significant vertical changes.
\end{abstract}

Descriptors: Extraoral traction appliances; malocclusion Angle Class II; orthodontics. 


\section{INTRODUCTION}

The use of headgear (HG) remains one of the most common strategies to correct Angle Class II malocclusion in growing patients. This class of malocclusion is present in a considerable percentage of the population ${ }^{1-4}$. In the southeast region of Brazil, its prevalence is 24.7 per cent 5 . Considering only individuals who sought orthodontic treatment, the prevalence achieves 50 per cent ${ }^{6}$.

The main factor to the success in treating this malocclusion is a correct diagnosis, which is obtained by the study of the patient's complete documentation. This material enables the orthodontist to develop an appropriate treatment plan. Another important aspect is the knowledge regarding the changes resulting from craniofacial growth and development, as well as the effects of orthodontic mechanics on the dental craniofacial complex ${ }^{7}$.

The HG appliance is indicated to restrict and to redirect maxillary growth and to distally move the upper molars $2,3,8-10$. The most appropriate period to use the HG coincides with the pubertal growth spurt. In this period, it is possible to achieve changes on deeper structures, such as the pterygomaxillary fissure ${ }^{10,11}$.

There are three possibilities to support the HG. The cervical anchorage is supported on the posterior region of the neck, and the parietal anchorage is supported on the upper region of the head. Another kind of anchorage is the occipital, supported on the posterior region of the head ${ }^{12}$. Each should be indicated according to the patient's skeletal pattern: hypo, hyper or mesiodivergent $2,13,14$.

There is not a complete consensus about the skeletal alterations produced by the HG associated with a full orthodontic appliance ${ }^{15,16}$. Therefore, the present study aims to evaluate the changes resulting from the use of $\mathrm{HG}$, with cervical and parietal anchorages, when associated with a full orthodontic appliance, in growing patients with Class II malocclusion treated at the clinic of an orthodontics postgraduate center.

\section{MATERIAL AND METHOD}

This retrospective study was approved by the local Research Ethics Committee of the Hospital Universitário Antônio Pedro, (protocol number 3190749).

\section{Retrieval of Clinical Case Files}

Diagnostic data, cephalometric records and clinical history of patients who completed orthodontic treatment at the Postgraduate Clinic in Orthodontics of Universidade Federal Fluminense were used in the study.

Were included in the study Class II patients younger than 14 years old that started and completed the orthodontic treatment at the University Clinic; whose data were appropriately described, including the HG records and the anchorage type (cervical or parietal).

Patients with non-Class II malocclusion and older than 14 years old, treated without HG or beyond the growth stage at the beginning of the HG therapy were excluded. The lack of data in the patient's documentation was another reason of exclusion from the study.

The hand-wrist radiography was used to confirm the growth stage by observing the presence of cartilage in the epiphyses of the long bones. 


\section{Data Collection}

All the archives of the Postgraduate Orthodontics Clinic were consulted. The data collected ranged from 1996 to 2018: Date of birth; sex; age at the beginning of treatment; Class of malocclusion (Angle); date of the beginning and the end of HG mechanics, as well as its duration, intensity, frequency, and anchorage type. The initial and final values of the variables SNA, SNB, ANB, AO-BO, GoGn.SN and LFH (per cent) (Figure 1) were also collected. Data were recorded in a Microsoft Excel spreadsheet (2007 version, Microsoft Office Corporation).

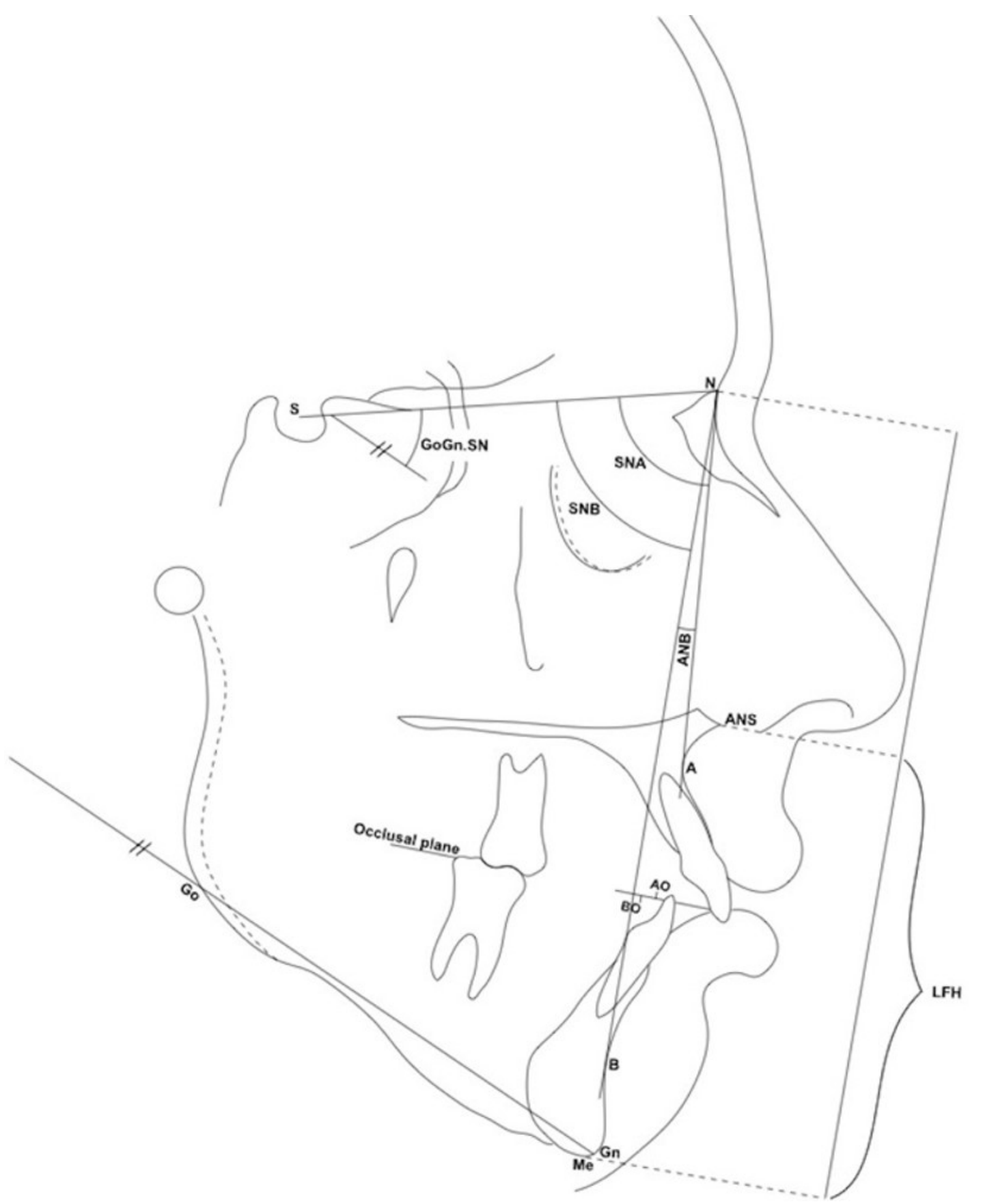

Figure 1. Cephalogram showing the variables used in the study.

Patients were instructed to use the HG for 15 hours a day. In each clinical consultation, in 15 days intervals, the force applied by the extra oral elastic was measured with the aid of a dynamometer 
(Morelli-Sorocaba, SP), so that it remained between 350 and 450 grams/force (g/f) during the treatment.

The headgear characteristics were as following: Outer bow parallel and $2.5 \mathrm{~cm}$ longer than the inner arch at the beginning of the treatment. The inner arch was expanded $0.5 \mathrm{~cm}$ in relation to the fitting tubes located in the first maxillary molars. The objective was to compensate the contraction of the inner arch caused by the elastic's traction. The patients were instructed to apply a mild pressure on the inner arch stop loops to insert or remove the appliance from the molar tubes.

When changes in the system were necessary, such as increasing the force on one side or compensating coronary inclination of first maxillary molars, small adjustments were be made in the outer bow, so that the most anterior portion of the appliance rested without pressure between the lips.

All patients presented Class II molar relationship (Angle ${ }^{1}$ ) before treatment. The value of ANB angle ranged between $3^{\circ}$ and $10^{\circ}$. None reported pain in the TMJ region.

\section{Statistical Treatment}

The Shapiro-Wilk test was applied to check the normality of the data. The Wilcoxon test (nonparametric data) and the paired $t$ test (parametric data) were used to assess the statistical significance of the results. The software Bioestat 5.3 (Belém - PA, Brazil) available at https://www.mamiraua.org.br/downloads/programas/ was used to perform the statistical tests.

\section{RESULT}

Nine hundred and eighty-five patients (100 per cent) were treated with fixed appliance. Three hundred and fifty-two (35.73 per cent) used HG. A hundred and thirty-two (13.4 per cent) were treated with cervical and 187 (19.0 per cent) with parietal anchorage. The occipital anchorage was applied in five patients ( 0.5 per cent). Cervical anchorage was replaced by occipital anchorage during treatment on 19 subjects ( 1.9 per cent). Two patients ( 0.2 per cent) started the treatment with parietal anchorage and later switched to occipital anchorage. In seven patients ( 0.7 per cent) the anchorage was not specified.

After applying the exclusion criteria, 56 files remained. File numbering has been converted to research-specific numbering, preserving patients' identities.

Twenty-six patients were male and 30 were female. The mean age at the beginning of treatment (T1) was 11 years and 6 months, ranging from 8 years and 11 months to 13 years and 11 months. The HG was used on average by 22 months. The applied force mean intensity was 400 grams/force $(\mathrm{g} / \mathrm{f})$.

Thirty patients were treated with cervical anchorage. At T1 the mean age was 11 years and 8 months (minimum of 9 years and 8 months and a maximum of 13 years and 11 months). At T2, the average age was 13 years and 6 months. The minimum age was 10 years and 11 months, and the maximum 16 years. The mean intensity of the applied force was $406 \mathrm{~g} / \mathrm{f}$.

Twenty-six patients were treated with parietal anchorage. At T1, the average age was 11 years and 5 months (8 years and 11 months to 13 years and 11 months). At T2, the average age was 13 years and 3 months (10 years to 15 years and 11 months). The mean intensity of the applied force was $395 \mathrm{~g} / \mathrm{f}$ (Table 1). 
Table 1. Characteristics of the sample

\begin{tabular}{|c|c|c|c|c|c|c|c|c|c|}
\hline & \multicolumn{9}{|c|}{ Cervical HG $(n=30)$} \\
\hline & \multirow{3}{*}{$\mathbf{n}$} & \multicolumn{6}{|c|}{ age } & \multirow{3}{*}{$\begin{array}{c}\text { intensity } \\
(\mathrm{g} / \mathrm{f})\end{array}$} & \multirow{3}{*}{$\begin{array}{c}\text { use } \\
\text { (months) }\end{array}$} \\
\hline & & \multicolumn{3}{|c|}{ T1 } & \multicolumn{3}{|c|}{$\mathrm{T} 2$} & & \\
\hline & & $\min$ & mean & $\max$ & $\min$ & mean & $\max$ & & \\
\hline Male & 14 & $9 y 8 m$ & $11 \mathrm{y} 8 \mathrm{~m}$ & $13 y 11 \mathrm{~m}$ & $10 \mathrm{y} 11 \mathrm{~m}$ & $13 y$ $7 \mathrm{~m}$ & $16 y$ & 396 & 23 \\
\hline Female & 16 & $10 \mathrm{y} 1 \mathrm{~m}$ & $11 \mathrm{y} 7 \mathrm{~m}$ & $13 y 10 m$ & $12 \mathrm{y} 2 \mathrm{~m}$ & $13 y 5 m$ & $15 y 8 m$ & 414 & 22 \\
\hline \multirow[t]{5}{*}{ Total } & 30 & $9 y 8 m$ & $11 \mathrm{y} 8 \mathrm{~m}$ & $13 \mathrm{y} 11 \mathrm{~m}$ & $10 \mathrm{y} 11 \mathrm{~m}$ & $13 y 6 m$ & $16 y$ & 406 & 22 \\
\hline & \multicolumn{9}{|c|}{ Parietal HG $(n=26)$} \\
\hline & \multirow{3}{*}{$\mathbf{n}$} & \multicolumn{6}{|c|}{ age } & \multirow{3}{*}{$\begin{array}{c}\text { intensity } \\
\text { (g/f) }\end{array}$} & \multirow{3}{*}{$\begin{array}{c}\text { use } \\
\text { (months) }\end{array}$} \\
\hline & & \multicolumn{3}{|c|}{$\mathbf{T 1}$} & \multicolumn{3}{|c|}{ T2 } & & \\
\hline & & $\min$ & mean & $\max$ & $\min$ & mean & $\max$ & & \\
\hline Male & 13 & $8 y 11 \mathrm{~m}$ & $11 \mathrm{y} 1 \mathrm{~m}$ & $12 \mathrm{y} 7 \mathrm{~m}$ & $10 y$ & $12 \mathrm{y} 11 \mathrm{~m}$ & $14 y 7 m$ & 398 & 22 \\
\hline Female & 13 & $9 y 1 \mathrm{~m}$ & $11 \mathrm{y} 9 \mathrm{~m}$ & $13 \mathrm{y} 11 \mathrm{~m}$ & $10 \mathrm{y} 9 \mathrm{~m}$ & $13 y 7 m$ & $15 \mathrm{y} 11 \mathrm{~m}$ & 392 & 22 \\
\hline Total & 26 & $8 y 11 \mathrm{~m}$ & $11 \mathrm{y} 5 \mathrm{~m}$ & $13 \mathrm{y} 11 \mathrm{~m}$ & $10 y$ & $13 y 3 m$ & $15 \mathrm{y} 11 \mathrm{~m}$ & 395 & 22 \\
\hline
\end{tabular}

$\mathrm{HG}=$ headgear; $\mathrm{T} 1$ = initial values; $\mathrm{T} 2$ = final values; $\mathrm{g} / \mathrm{f}=$ grams/force.

The initial (T1) and final (T2) values of the variables studied (SNA, SNB, ANB, AO-BO, GoGn.SN, and LFH) of each patient, as well as the differences between $\mathrm{T} 1$ and $\mathrm{T} 2$, were recorded in two new worksheets according to anchorage type to perform the statistical tests.

Table 2 presents the data of the patients treated with cervical anchorage. There was a statistically significant increase for the SNB variable $(p=0.00)$, whose mean value increased from $75.9^{\circ}$ to $77.1^{\circ}$. The ANB $(p=0.00)$ and AO-BO $(p=0.01)$ variables showed a statistically significant decrease in their mean values, from $5.1^{\circ}$ to $3.3^{\circ}$ and from $2.8 \mathrm{~mm}$ to $1.4 \mathrm{~mm}$, respectively. The other variables did not present statistically significant differences from $\mathrm{T} 1$ to $\mathrm{T} 2$.

Table 2. Mean values of the cervical HG group. Standard Deviation (SD), minimum and maximum values, mean differences between T1 and T2, and $p$-value

\begin{tabular}{|c|c|c|c|c|c|c|c|}
\hline \multirow{2}{*}{ Variables } & \multicolumn{7}{|c|}{ cervical HG $(n=30)$} \\
\hline & phase & mean & SD & $\min$ & $\max$ & T2-T1 & $p$-value \\
\hline \multirow{2}{*}{ SNA } & $\mathrm{T} 1$ & 81.0 & 4.8 & 70.0 & 90.0 & \multirow{2}{*}{-0.9} & \multirow{2}{*}{0.06} \\
\hline & $\mathrm{T} 2$ & 80.1 & 5.1 & 69.0 & 89.0 & & \\
\hline \multirow{2}{*}{ SNB } & $\mathrm{T} 1$ & 75.9 & 4.0 & 67.0 & 84.0 & \multirow{2}{*}{1.2} & \multirow{2}{*}{$0.00 *$} \\
\hline & $\mathrm{T} 2$ & 77.1 & 4.4 & 70.0 & 88.0 & & \\
\hline \multirow{2}{*}{ ANB } & $\mathrm{T} 1$ & 5.1 & 2.5 & 3.0 & 10.0 & \multirow{2}{*}{-1.8} & \multirow{2}{*}{$0.00^{*}$} \\
\hline & $\mathrm{T} 2$ & 3.3 & 2.5 & -2.0 & 11.0 & & \\
\hline \multirow{2}{*}{ AO-BO } & $\mathrm{T} 1$ & 2.8 & 3.0 & -3.0 & 9.0 & \multirow{2}{*}{-1.4} & \multirow{2}{*}{$0.02 *$} \\
\hline & $\mathrm{T} 2$ & 1.4 & 2.7 & -5.0 & 8.0 & & \\
\hline \multirow{2}{*}{ GoGn.SN } & $\mathrm{T} 1$ & 32.8 & 4.4 & 25.0 & 43.0 & \multirow{2}{*}{-1.0} & \multirow{2}{*}{0.11} \\
\hline & $\mathrm{T} 2$ & 31.8 & 5.2 & 23.0 & 41.0 & & \\
\hline \multirow{2}{*}{ LFH } & $\mathrm{T} 1$ & 55.4 & 3.5 & 49.0 & 64.9 & \multirow{2}{*}{0.4} & \multirow{2}{*}{0.45} \\
\hline & $\mathrm{T} 2$ & 55.8 & 2.5 & 50.0 & 63.0 & & \\
\hline
\end{tabular}

*Statistically significant.

Table 3 presents data regarding patients treated with parietal anchorage. A statistically significant increase was observed for the SNB variable $(p=0.05)$, whose mean value increased from $74.8^{\circ}$ to $75.7^{\circ}$. The ANB variable $(p=0.00)$ showed a statistically significant decrease in its mean values, from $5.0^{\circ}$ to $3.8^{\circ}$. The other variables did not present statistically significant differences from $\mathrm{T} 1$ to $\mathrm{T} 2$. 
Table 3. Mean values of the parietal HG group. Standard Deviation (SD), minimum and maximum values, mean differences between T1 and T2, and $p$-value

\begin{tabular}{|c|c|c|c|c|c|c|c|}
\hline \multirow{2}{*}{ Variables } & \multicolumn{7}{|c|}{ parietal HG $(n=26)$} \\
\hline & phase & mean & SD & $\min$ & $\max$ & T2-T1 & $p$-value \\
\hline \multirow{2}{*}{ SNA } & T1 & 79.9 & 3.0 & 73.0 & 86.0 & \multirow{2}{*}{-0.3} & \multirow{2}{*}{0.56} \\
\hline & $\mathrm{T} 2$ & 79.5 & 3.3 & 71.0 & 84.0 & & \\
\hline \multirow{2}{*}{ SNB } & $\mathrm{T} 1$ & 74.8 & 2.6 & 70.0 & 80.0 & \multirow{2}{*}{0.9} & \multirow{2}{*}{$0.05^{*}$} \\
\hline & T2 & 75.7 & 3.1 & 67.0 & 82.0 & & \\
\hline \multirow{2}{*}{ ANB } & $\mathrm{T} 1$ & 5.0 & 2.3 & 3.0 & 10.0 & \multirow{2}{*}{-1.2} & \multirow{2}{*}{$0.01^{*}$} \\
\hline & $\mathrm{T} 2$ & 3.8 & 2.0 & 0.0 & 9.0 & & \\
\hline \multirow{2}{*}{ AO-BO } & $\mathrm{T} 1$ & 1.8 & 2.2 & -3.0 & 6.0 & \multirow{2}{*}{-0.2} & \multirow{2}{*}{0.49} \\
\hline & $\mathrm{T} 2$ & 1.6 & 2.9 & -4.0 & 7.0 & & \\
\hline \multirow{2}{*}{ GoGn.SN } & $\mathrm{T} 1$ & 36.4 & 4.9 & 26.0 & 49.0 & \multirow{2}{*}{0.3} & \multirow{2}{*}{0.49} \\
\hline & $\mathrm{T} 2$ & 36.7 & 4.5 & 29.0 & 50.0 & & \\
\hline \multirow{2}{*}{ LFH } & $\mathrm{T} 1$ & 57.3 & 2.6 & 53.5 & 65.0 & \multirow{2}{*}{-0.1} & \multirow{2}{*}{0.73} \\
\hline & $\mathrm{T} 2$ & 57.2 & 3.1 & 51.0 & 64.0 & & \\
\hline
\end{tabular}

*Statistically significant.

\section{DISCUSSION}

This research aimed to evaluate the skeletal changes resulting from the use of $\mathrm{HG}$ with cervical and parietal anchorages, when associated with fixed orthodontic appliance, in a universe of patients treated according to the same principles of orthodontic mechanics. As no statistically significant differences were found between boys and girls, the sample was not divided according to sex.

The use of HG has varied over time. Between the mid-1980s and 1990s, it increased significantly. After that occurred a decrease due to new treatment options of Class II malocclusion (Angle ${ }^{1}$ ). In the current sample, collected from onwards 1996, it was observed that 35.73 per cent of the patients used $\mathrm{HG}$, a percentage higher than what would be expected for the period ${ }^{17}$.

In a previous prospective study, it was observed that cervical anchorage significantly reduced the maxillomandibular sagittal discrepancy. When the HG was used without the installation of the fixed appliance, the restriction of anterior maxilla displacement and forward displacement of the mandible contributed to this result, but without statistical significance ${ }^{18}$.

The current data partially support these conclusions. The sagittal discrepancy between the maxillary bones was effectively reduced, what was demonstrated by the significant decrease in ANB angle $(p=0.00)$ and AO-BO linear distance $(p=0.01)$. This reduction occurred much more due to the anterior displacement of the mandible, revealed by the increase of the SNB angle $(p=0.00)$ than by the restriction of the anterior maxilla displacement $(p=0.10)$. Another similarity was the non-significant increase in the vertical height of the face. The favorable growth of the condyle and of the alveolar region are the possible factors that inhibited changes in the mandibular plane inclination (GoGn.SN), compensating the maxillary molars' extrusion and inclination, as a consequence of the cervical mechanics ${ }^{2,9,18,19}$.

Studies that evaluated the effects of the cervical HG associated with the fixed appliance ${ }^{15,20-22}$ or the lower base $\operatorname{arch}^{23}$ also found a significant reduction in ANB values. Some authors ${ }^{21,23}$ ascribed the sagittal discrepancy reduction to the significant mandible growth, while others found only significant changes in anterior maxillary displacement restriction. Vertical changes were not considered statistically significant $15,22,23$, except in Baccetti et al. ${ }^{21}$ study.

Similar changes were observed regarding patients treated with parietal anchorage. There was a decrease in the sagittal discrepancy between the maxilla and the mandible, with significant decrease of the ANB value $(p=0.00)$. The AO-BO linear distance, however, did not show a statistically significant reduction $(p=0.49)$. The sagittal discrepancy decrease was due to the 
increased SNB angle value ( $p=0.05$ ), and consequently to a more anterior mandible positioning. The variables GoGn.SN and LFH (per cent) did not show statistical differences from T1 to T2, demonstrating that there were no significant vertical changes with the use of this kind of anchorage.

Bilbo et al. ${ }^{16}$ concluded that parietal anchorage was responsible for the ANB reduction and for the growth forwards restriction of point $A$, while the mandible maintained a continuous forward growth. Antonarakis, Kiliaridis ${ }^{15}$ verified that both anchorages presented a significant reduction of the SNA and ANB angles, while the increments in the SNB and mandibular plane angles were not significant.

A common result found by several researchers was the reduction of the sagittal discrepancy between the maxillary bones, necessary for the correction of Class II malocclusion. Little discrepancies between the findings are probably due to the peculiarities of the samples studied.

One of the current research limitations was the impossibility of evaluating the patients' compliance regarding the use of headgear. Another limitation is that the HG mechanics was associated with the fixed appliance, installed in the upper arch, making it difficult to state that the changes found were exclusively due to application of HG. It was also not possible to obtain the variables' values immediately after the HG appliance removal. The T2 values refer to the end of orthodontic treatment. As patients were in the growing stage, the alterations produced on the GoGn.SN angle, for example, may have changed during this period.

Oosthuizen et al. ${ }^{24}$ and Jacobson ${ }^{25}$ theoretically demonstrated the extrusive character of cervical anchorage, as well as the intrusive tendency of parietal anchorage. Anchorage selection followed what was recommended by these authors. The mean GoGn.SN angle value at T1 was $32.8^{\circ}$ for the cervical anchorage group, rising to $36.4^{\circ}$ for the parietal anchorage group. In the period of time between the removal of the $\mathrm{HG}$ and the obtaining of final radiographs, the growth pattern inherent to patients in both groups could manifest itself freely, which could explain the differences in the mean values corresponding to this angle between T1 and T2 $\left(-1.0^{\circ}\right.$ and $0.3^{\circ}$, for cervical and parietal groups, even after using theoretically extrusive and intrusive mechanics, respectively).

Therefore, it is suggested that further studies be carried out, in which these limitations can be eliminated.

\section{CONCLUSION}

Skeletal changes resulting from the use of cervical and parietal headgears were very similar. There was a decrease in the sagittal discrepancy between the maxillary bones due to forward displacement of the mandible, without significant vertical changes.

\section{REFERENCES}

1. Angle EH. Classification of malocclusion. Dental Cosmos. 1899 Mar;41(3):248-64.

2. Farret MM, Lima EM, Araújo VP, Rizzatto SMD, Menezes LM, Grossi ML. Molar changes with cervical headgear alone or in combination with rapid maxillary expansion. Angle Orthod. 2008 Sep;78(5):84751. http://dx.doi.org/10.2319/080207-360.1. PMid:18298206.

3. Henriques FP, Janson G, Henriques JFC, Pupulim DC. Effects of cervical headgear appliance: a systematic review. Dental Press J Orthod. 2015 Jul-Aug;20(4):76-81. http://dx.doi.org/10.1590/21769451.20.4.076-081.oar. PMid:26352849. 
4. Kirjavainen M, Hurmerinta K, Kirjavainen T. Facial profile changes in early class II correction with cervical headgear. Angle Orthod. 2007 Nov;77(6):960-7. http://dx.doi.org/10.2319/092106-384. PMid:18004917.

5. Baptista AA, Galindo AGS, Pinheiro CC, Motta AFJ, Vilella OV, Mucha JN. A prevalência de maloclusões em escolares de Niterói - 1ª parte. Rev Flumin Odontol. 1997;6(1):12-6.

6. Freitas MR, Freitas DS, Pinheiro FHSL, Freitas KMS. Prevalência das más oclusões em pacientes inscritos para tratamento ortodôntico na Faculdade de Odontologia de Bauru. Rev Fac Odontol Bauru. 2002;10(3):164-9.

7. Nanda RS. The contributions of craniofacial growth to clinical orthodontics. Am J Orthod Dentofacial Orthop. 2000 May;117(5):553-5. http://dx.doi.org/10.1016/S0889-5406(00)70197-1. PMid:10799112.

8. Maruo IT, Maruo H, Saga AY, Oliveira DD, Argenta MA, Tanaka OM. Tridimensional finite element analysis of teeth movement induced by different headgear forces. Prog Orthod. 2016 Dec;17(1):18. http://dx.doi.org/10.1186/s40510-016-0130-4. PMid:27264500.

9. Phan XL, Schneider BJ, Sadowsky C, BeGole EA. Effects of orthodontic treatment on mandibular rotation and displacement in Angle class II division 1 malocclusions. Angle Orthod. 2004 Apr;74(2):174-83. PMid:15132443.

10. Piva LM, Brito HHA, Leite HR, O'Reilly M. Effects of cervical headgear and fixed appliances on the space available for maxillary second molars. Am J Orthod Dentofacial Orthop. 2005 Sep;128(3):366-71. http://dx.doi.org/10.1016/j.ajodo.2004.04.032. PMid:16168333.

11. Wieslander L. The effect of orthodontic treatment on the concurrent development of the craniofacial complex. Am J Orthod. 1963 Jan;49(1):15-27. http://dx.doi.org/10.1016/0002-9416(63)90063-0.

12. Barton JJ. High-pull headgear versus cervical traction: a cephalometric comparison. Am J Orthod. 1972 Nov;62(5):517-29. http://dx.doi.org/10.1016/0002-9416(72)90027-9. PMid:4507143.

13. Casaccia GR, Gomes JC, Squeff LR, Penedo ND, Elias CN, Gouvêa JP, et al. Analysis of initial movement of maxillary molars submitted to extraoral forces: a 3D study. Dental Press J Orthod. 2010 Out;15(5):379. http://dx.doi.org/10.1590/S2176-94512010000500006.

14. Ibitayo AO, Pangrazio-Kulbersh V, Berger J, Bayirli B. Dentoskeletal effects of functional appliances vs bimaxillary surgery in hyperdivergent class II patients. Angle Orthod. 2011 Mar;81(2):304-11. http://dx.doi.org/10.2319/060110-297.1. PMid:21208084.

15. Antonarakis GS, Kiliaridis S. Treating Class II malocclusion in children. Vertical skeletal effects of highpull or low-pull headgear during comprehensive orthodontic treatment and retention. Orthod Craniofac Res. 2015 May;18(2):86-95. http://dx.doi.org/10.1111/ocr.12062. PMid:25545335.

16. Bilbo EE, Marshall SD, Southard KA, Allareddy V, Holton N, Thames AM, et al. Long term skeletal effects of high-pull headgear followed by fixed appliances for the treatment of class II malocclusions. Angle Orthod. 2018 Sep;88(5):530-7. http://dx.doi.org/10.2319/091517-620.1. PMid:29667470.

17. Tüfekçi E, Allen SB, Best AM, Lindauer SJ. Current trends in headgear use for the treatment of class II malocclusions. Angle Orthod. 2016 Jul;86(4):584-9. http://dx.doi.org/10.2319/041315-242.1. PMid:26401825.

18. Rosa AJ, Nascimento RR, Mucha JN, Vilella OV. Effects of the cervical headgear in growing Angle Class II malocclusion patients: a prospective study. Dental Press J Orthod. 2020 Apr;25(2):25-31. http://dx.doi.org/10.1590/2177-6709.25.2.025-031.oar. PMid:32490924.

19. Lima RMA Fo, Lima AL, Ruellas ACO. Mandibular changes in skeletal class II patients treated with Kloehn cervical headgear. Am J Orthod Dentofacial Orthop. 2003 Jul;124(1):83-90. http://dx.doi.org/10.1016/S0889-5406(03)00237-3. PMid:12867902.

20. Almeida-Pedrin RR, Henriques JFC, Almeida RR, Almeida MR, McNamara JA Jr. Effects of the pendulum appliance, cervical headgear, and 2 premolar extractions followed by fixed appliances in patients with 
Class II malocclusion. Am J Orthod Dentofacial Orthop. 2009 Dec;136(6):833-42.

http://dx.doi.org/10.1016/j.ajodo.2007.12.032. PMid:19962606.

21. Baccetti T, Franchi L, Stahl F. Comparison of 2 comprehensive Class II treatment protocols including the bonded Herbst and headgear appliances: a double-blind study of consecutively treated patients at puberty. Am J Orthod Dentofacial Orthop. 2009 Jun;135(6):698.e1-10.

http://dx.doi.org/10.1016/j.ajodo.2008.03.015. PMid:19524823.

22. Lione R, Franchi L, Laganà G, Cozza P. Effects of cervical headgear and pendulum appliance on vertical dimension in growing subjects: a retrospective controlled clinical trial. Eur J Orthod. 2015 Jun;37(3):338-44. http://dx.doi.org/10.1093/ejo/cju061. PMid:25316493.

23. Tamburús VS, Pereira JS No, Siqueira VCV, Tamburús WL. Treatment effects on class II division 1 high angle patients treated according to the bioprogressive therapy (cervical headgear and lower utility arch), with emphasis on vertical control. Dental Press J Orthod. 2011 May-June;16(3):70-8.

24. Oosthuizen L, Dijkman JF, Evans WG. A mechanical appraisal of the Kloehn extraoral assembly. Angle Orthod. 1973 Jul;43(3):221-32. PMid:4515770.

25. Jacobson A. A key to the understanding of extraoral forces. Am J Orthod. 1979 Apr;75(4):361-86. http://dx.doi.org/10.1016/0002-9416(79)90159-3. PMid:285613.

\section{CONFLICTS OF INTERESTS}

The authors declare no conflicts of interest.

\section{*CORRESPONDING AUTHOR}

Anderson Jaña Rosa, UFF - Universidade Federal Fluminense, Faculdade de Odontologia, Departamento de Ortodontia, Rua Mário Santos Braga, 30, $2^{\circ}$ andar, sala 214, Centro, Campus do Valonguinho, 24020-140 Niterói - RJ, Brasil, e-mail: andersonjanarosa@id.uff.br.

Received: April 22, 2021

Accepted: October 21, 2021 